\title{
Phage displayed domain antibody mimics for pyrethroid and its application in immunoassay
}

\author{
Yanyan Zhao ${ }^{1}$, Ying Liang ${ }^{2}$, Yuan Liu², Sicong Tư ${ }^{4}$, Shengming Zhao ${ }^{1}$, Xianjin $\mathrm{Liu}^{2 *}$, Kang $\mathrm{Tu}^{3 *}$ \\ (1. School of Food Science and technology, Henan Institute of Science and Technology, Xinxiang 453003, China; \\ 2. Key Laboratory of Food Quality and Safety of Jiangsu Province-State Key Laboratory Breeding Base, Key Laboratory of Control \\ Technology and Standard for Agri-product Safety and Quality, Ministry of Agriculture and Rural Affairs, Institute of Agricultural Product \\ Quality Safety and Nutrition Research, Jiangsu Academy of Agricultural Sciences, Nanjing 210014, China; \\ 3. College of Food Science and Technology, Nanjing Agricultural University, Nanjing 210095, China; \\ 4. School of Medical Sciences, University of New South Wales, Sydney, NSW 2052, Australia)
}

\begin{abstract}
Anti-idiotypic antibodies which can mimic antigens have many potential applications in the immunoassay. This research used the monoclonal antibody of the conserved chemical region of pyrethroids, 3-phenoxybenzoic acid (PBA), and the domain antibody library to develop an environmentally-friendly immunoassay for the detection of pyrethroids. The domain antibodies (A8, B8, and C6) which bound to anti-PBA monoclonal antibody (MAb) were isolated from a naive phage display human domain antibody library. This domain antibody is cloneable, pyrethroid-free, and applicable as a competitive mimetic antigen in the immunoassay. The best immunoassay was achieved using $\mathrm{A} 8$, resulting in $\mathrm{IC}_{50}$ of $0.714 \mu \mathrm{g} / \mathrm{mL}$ for $\mathrm{PBA}$, $1.775 \mu \mathrm{g} / \mathrm{mL}$ for Cypermethrin, $1.624 \mu \mathrm{g} / \mathrm{mL}$ for $\beta$-cypermethrin, $3.675 \mu \mathrm{g} / \mathrm{mL}$ for Fenvalerate, and $4.895 \mu \mathrm{g} / \mathrm{mL}$ for Flucythrinate. This way of selecting anti-idiotypic antibodies to detect pyrethroids could provide potential applications in developing immunoassays for identifying various chemical contaminants in food.
\end{abstract}

Keywords: domain antibody, enzyme-linked immunosorbent assay, phenoxybenzoic acid, pyrethroid DOI: $10.25165 /$ j.ijabe.20201302.5492

Citation: Zhao Y Y, Liang Y, Liu Y, Tu S C, Zhao S M, Liu X J, et al. Phage displayed domain antibody mimics for pyrethroid and its application in immunoassay. Int J Agric \& Biol Eng, 2020; 13(2): 235-240.

\section{Introduction}

The presence of small molecule chemical contaminants, such as pesticides, mycotoxins, antibiotics and veterinary drugs in foods have attracted great attentions of society since they pose a serious threat to human health. It is necessary to develop a simple and rapid analytical technique for monitoring the residue of small chemicals in foods and feedstuffs ${ }^{[1,2]}$. Immunoassays are widely used as analytical techniques for such a purpose due to their high sensitivity, specificity, speed, and low cost, easy to operate and high throughput ${ }^{[3-5]}$.

Unlike large molecules, since the small analytes cannot be recognized by two antibodies at the same time, they can not be detected by a sandwich immunoassay. Therefore, a competitive immunoassay is needed, in which the hapten-protein conjugate and the target competitively bind to the antibody. Unfortunately, the conventional competing antigens used for the development of a

\section{Received date: 2019-10-30 Accepted date: 2020-02-29}

Biographies: Yanyan Zhao, $\mathrm{PhD}$, research interests: food safety and control, Email: zhaoyanyan@hist.edu.cn; Ying Liang, $\mathrm{PhD}$, research interests: food safety and control, Email: 64952509@qq.com; Yuan Liu, PhD, research interests: food safety and control, Email: liuyuan@jaas.ac.cn; Sicong Tu, PhD, research interests: medicine, Email: 75717739@qq.com; Shengming Zhao, PhD, research interests: meat safety and control, Email: zhaoshengming@ hist.edu.cn. *Corresponding author: Xianjin Liu, Professor, research interests: food safety and control. Mailing address: Key Laboratory of Food Quality and Safety of Jiangsu Province, Institute of Food Safety and Nutrition, Jiangsu Academy of Agricultural Science, Nanjing 210014, China. Tel: +86-25-84390176, Email: jaasliu@jaas.ac.cn; Kang Tu, Professor, research interests: nondestructive detection, storage and processing of agricultural products. Mailing address: College of Food Science and Technology, Nanjing Agricultural University, Nanjing 210095, China. Tel: +86-25-84399016, Email: kangtu@njau.edu.cn. competitive immunoassay are synthesized by a chemical process. Synthesizing conventional competing antigens are time consuming, complex procedures, and the use of organic solvent. Especially when the hapten is toxic, it may lead a threat to environment and human health ${ }^{[6,7]}$. Therefore, it is important in developing an environment-friendly method to obtain the competing antigens.

Anti-idiotypic antibodies could be used as competing antigens instead of the conventional hapten-protein conjugates because of its ability of mimicking antigens. Anti-idiotype antibodies against large or small molecules have been developed by monoclonal ${ }^{[8,9]}$ or polyclonal $^{[10,11]}$ techniques. Since phage displayed library firstly reported $^{[12]}$, it has been widely used for including screening antibodies and anti-idiotypic antibodies. The antibodies and anti-idiotypic antibodies screened from phage displayed library could be used effectively for detection of small molecules, such as aflatoxin $^{[13,14]}$ ochratoxin ${ }^{[15]}$ monensin ${ }^{[16]}$, atrazine ${ }^{[17]}$, thiacloprid $^{[18]}$, deoxynivalenol ${ }^{[19]}$, and zearalenone ${ }^{[20]}$. However, there has not been any reported on select anti-idiotype antibodies against pyrethroids from the naive phage display domain antibodies. However, contaminants which have similar structure usually are present in samples at the same time ${ }^{[21]}$. Thus, multianalyte immunoassays used to determine the similar contaminants synchronously in a single test have attracted more attention ${ }^{[22]}$. In this study, we aim to select an anti-idiotypic antibody against pyrethroids from phage display domain antibodies and study its application in multianalyte immunoassay.

Anti-PBA MAb as a model antigen which can recognize several pyrethroids ${ }^{[23]}$ was used for selecting the anti-idiotypic antibody from phage display domain antibodies in this present work. Finally, we developed an immunoassay for detecting pyrethroids based on the anti-idiotypic antibody. The 
immunoassay for pyrethroids was established by using anti-PBA $\mathrm{MAb}$ as a coating compound and the phage of positive clones as the competing antigen.

\section{Materials and methods}

\subsection{Materials and Reagents}

All the pyrethroids were purchased from Institute for the Control of Agrochemicals. 3-phenoxybenzoic acid (PBA), skim milk (M), bovine serum albumin (BSA), tween 20, 3,3',5,5'tetramethylbenzidine (TMB), and polyethylene glycol 6000 (PEG 6000) were obtained from Sigma Chemical Co. (New Jersey, USA). The other reagents and anti-M13 horseradish-peroxidase (HRP) conjugate were purchased from GE Healthcare (Beijing, China). The sequencing primers were synthesized by Sangon Biotech (Shanghai, China). The monoclonal antibody of PBA (anti-PBA $\mathrm{MAb}$ ) was a gift from Dr. Yuan Liu (Institute of Food Quality Safety and Detection Research, Jiangsu Academy of Agricultural Sciences). The human domain antibody library, helper phage KM13 and Escherichia coli TG1 were provided by MRC Laboratory of Molecular Biology (Cambridge, England). The antibodies were constructed with CDR1 region, CDR2 region and $\mathrm{CDR} 3$ region. All chemical reagents were of analytical grade.

\subsection{Biopanning of domain antibodies binding to anti-PBA} MAb

A naive phage display domain antibody library with the size of $3 \times 10^{9}$ was used for biopanning of domain antibodies which bind to anti-PBA MAb. The strategy of selection was performed by four rounds selection, and competitive elution was carried out in the biopanning. Briefly, 6-well plate (MaxiSorp, Nunc) was coated with $1 \mathrm{~mL}$ anti-PBA MAb overnight at $4^{\circ} \mathrm{C}$, the well was washed 3 times with PBS and was blocked with $2 \%$ MPBS overnight at $4{ }^{\circ} \mathrm{C}$. After washed with PBS for 3 times, the well coated with anti-PBA MAb was added with $1 \mathrm{ml}$ of phage library in $2 \%$ MPBS, and was incubated for one hour with gentle shaking. The unbound phages were washed away with PBST and the bound phages were eluted by anti-PBA MAb competitively. Finally, eluted phages were amplified for the following panning.

\subsection{Identification of selected domain antibody}

The ability of the positive clones to bind with anti-PBA MAb were confirmed by monoclonal phage ELISA. The eluted phages from the last round of elution were used to infect $E$. coli TG1 cells, then E. coli TG1 were cultured on TYE plates (containing $100 \mu \mathrm{g} / \mathrm{mL}$ ampicillin and $4 \%$ glucose) overnight at $37^{\circ} \mathrm{C}$. Individual clones were picked randomly and inoculated into the $2 \times \mathrm{TY}$ medium (containing $100 \mu \mathrm{g} / \mathrm{mL}$ ampicillin and $4 \%$ glucose). They were cultured overnight at $37^{\circ} \mathrm{C}$ with shaking at $250 \mathrm{r} / \mathrm{min}$. $2 \mu \mathrm{L}$ culture was transferred to $200 \mu \mathrm{L} 2 \times \mathrm{TY}$ medium (containing $100 \mu \mathrm{g} / \mathrm{mL}$ ampicillin and $4 \%$ glucose) and cultured at $37^{\circ} \mathrm{C}$ with shaking at $250 \mathrm{r} / \mathrm{min}$ for about two hours until the $\mathrm{OD}_{600 \mathrm{~nm}}=0.5$. The helper phage KM13 was added to the culture and incubated for one hour at $37^{\circ} \mathrm{C}$. The bacteria were collected by centrifugation and re-suspended in $2 \times \mathrm{TY}$ medium (containing $100 \mu \mathrm{g} / \mathrm{mL}$ ampicillin, $50 \mu \mathrm{g} / \mathrm{mL}$ kanamycin and $0.1 \%$ glucose). The culture was incubated overnight at $25^{\circ} \mathrm{C}$ with shaking at $250 \mathrm{r} / \mathrm{min}$. $100 \mu \mathrm{L}$ of supernatant were added to 96 wells plates which were coated with $2 \mu \mathrm{g} / \mathrm{mL}$ of anti-PBA MAb and blocked with $2 \%$ bovine serum albumin (BSA), at the same time the wells coated with $2 \mu \mathrm{g} / \mathrm{mL}$ of BSA as the negative. Then anti-M13 horseradish-peroxidase (HRP) conjugates were added and incubated in the wells. Finally, peroxidase substrate was added to the wells. The reaction was stopped by adding $2 \mathrm{M} \mathrm{H}_{2} \mathrm{SO}_{4}$ and the absorbance of $450 \mathrm{~nm}$ was read by using a microplate reader. Before each procedure the wells were washed with PBST, except the last one.

Positive clones which were identified by ELISA would be further verified by bacteria PCR, and the primers were DAB-F2 (5'- A G G T G C A G C T G T T G G A G T C T G -3'), and DAB-R2 (5'- T C G A G A C G G T G A C C A G G G T T -3'). The PCR products were analyzed by agarose gel electrophoresis. Finally, the positive clones were sequenced with the primer (5'- C C C T C A T A G T T A G C G T A A C G A -3'). The positive clones were translated from the nucleotide sequences (according to http://web.expasy.org/translate/).

\subsection{Production of selected domain antibody}

The confirmed positive clones were cultured to amplify the phages. The clones were cultured overnight at $37^{\circ} \mathrm{C}$ with shaking at $250 \mathrm{r} / \mathrm{min}$. A sample of $5 \mathrm{~mL}$ culture was transferred into $500 \mathrm{~mL} 2 \times \mathrm{TY}$ medium (containing $100 \mu \mathrm{g} / \mathrm{mL}$ ampicillin and $4 \%$ glucose) and cultured at $37^{\circ} \mathrm{C}$ with shaking at $250 \mathrm{r} / \mathrm{min}$ until the $\mathrm{OD}_{600 \mathrm{~nm}}=0.5$. The $10^{11}$ helper phages $\mathrm{KM} 13$ were added and incubated for one hour at $37^{\circ} \mathrm{C}$. The bacteria were collected by centrifuging $\left(3200 \mathrm{~g}\right.$ for $10 \mathrm{~min}$ ) at $4^{\circ} \mathrm{C}$ and re-suspended with $500 \mathrm{~mL} 2 \times \mathrm{TY}$ medium (containing $100 \mu \mathrm{g} / \mathrm{mL}$ ampicillin, $50 \mu \mathrm{g} / \mathrm{mL}$ kanamycin and $0.1 \%$ glucose). The culture was incubated overnight at $25^{\circ} \mathrm{C}$ with shaking at $250 \mathrm{r} / \mathrm{min}$. After centrifugation of overnight culture (3200g for $30 \mathrm{~min}), 100 \mathrm{~mL}$ PEG/NaCl (20\% polyethylene glycol, $2.5 \mathrm{M} \mathrm{NaCl}$ ) was added to the supernatant. The mixture was incubated on ice for one hour and then spun $(3200 \mathrm{~g}$ for $30 \mathrm{~min})$ once more. The pellets were re-suspended in PBS and the mixture was precipitated by $\mathrm{PEG} / \mathrm{NaCl}$ for one more time. Finally, the pellets were re-suspended in PBS and spun (3200 $\mathrm{g}$ for $30 \mathrm{~min}$ ) at $4{ }^{\circ} \mathrm{C}$ again to remove any bacterial debris. The titer of the phages was determined and the phages were stored at $-80^{\circ} \mathrm{C}$ after adding glycerol.

\subsection{Domain antibody-based competitive immunoassay for pyrethroids}

To obtain the optimized dilution of domain antibody and anti-PBA MAb, a checkerboard titration analysis was performed by using a different dilution of them in advance. Serial dilutions of phage were added to the wells coated with different concentrations of anti-PBA MAb $(2,1,0.5,0.25$, and $0 \mu \mathrm{g} / \mathrm{mL})$.

The wells of a 96-well plate were coated with anti-PBA MAb overnight at $4{ }^{\circ} \mathrm{C}$. The wells were blocked with $2 \%$ bovine serum albumin (BSA). $50 \mu \mathrm{L}$ of pyrethroid standards at concentrations from 0.078125 to $20 \mu \mathrm{g} / \mathrm{mL}$ (or sample extracts) and $50 \mu \mathrm{L}$ domain antibody were added. The mixtures were incubated for one hour at $37^{\circ} \mathrm{C} . \quad 100 \mu \mathrm{L}$ of the anti-M13 horseradish-peroxidase (HRP) conjugate (1:5000 diluted in PBS) was added to the wells and incubated at $37^{\circ} \mathrm{C}$ for one hour. $100 \mu \mathrm{L}$ TMB substrate was used. After $15 \mathrm{~min}$, the reaction was stopped by adding $50 \mu \mathrm{L}$ of $2 \mathrm{M}$ $\mathrm{H}_{2} \mathrm{SO}_{4}$. Before each procedure the wells were washed with PBST, except the last one. The absorbance of the wells was detected at $450 \mathrm{~nm}$ by a microplate reader. Results were shown as $\mathrm{IC}_{50}$.

\subsection{Matrix effect and samples analysis}

Chinese cabbage was chosen to study matrix effect on the domain antibody-based competitive immunoassay. $1 \mu \mathrm{g} / \mathrm{mL}$ and $2 \mu \mathrm{g} / \mathrm{mL}$ of pyrethroids were added to the pyrethroids free Chinese cabbage matrices, 2 times matrices dilution, and 4 times matrices dilution, respectively. The mixtures were detected by the ELISA developed with domain antibody. To evaluate the recovery of domain antibody-based immunoassay, $20 \mathrm{~g}$ pyrethroid free samples 
verified by GC were spiked with pyrethroids at the concentrations of $2.0 \mu \mathrm{g} / \mathrm{mg}$ and $3.0 \mu \mathrm{g} / \mathrm{mg}$, respectively. After $30 \mathrm{~min}, 20 \mathrm{~mL}$ acetonitrile, $8.0 \mathrm{~g} \mathrm{Na}_{2} \mathrm{SO}_{4}$ and $3.0 \mathrm{~g} \mathrm{NaCl}$ were added. The mixture was strongly shaken for one minute and spun at $4000 \mathrm{r} / \mathrm{min}$ for $30 \mathrm{~min}$. The supernatants were dried by nitrogen evaporator and re-dissolved in $10 \%$ methanol-PBS, and the solutions were used as sample extract. The ELISA assay was carried out as well as 2.5 .

\section{Results and discussion}

\subsection{Selection and identification of positive phage displayed} domain antibody

The ability of the library to bind to anti-PBA MAb was detected by polyclonal ELISA. The polyclonal ELISA result of the fourth round was 5 times higher than that of the original library (Figure 1). Positive clones were identified by monoclonal phage ELISA (Figure 2), PCR identification (Figure 3) and DNA sequencing. Then three unique sequences were obtained and presented in Figure 4. Finally, three different phage clones (A8, B8, C6) which was illustrated strong binding capacity to anti-PBA MAb were obtained in present study. This result demonstrated that our strategy was successful in the selection of positive domain antibody clones.

As the DAB library has been described previously ${ }^{[24]}$, the framework regions of the three sequences are highly conserved (Figure 4). There is only one amino acid being identical in the CDR1 region and three amino acids being identical in the CDR2 region while the total numbers of amino acids remain the same. The amino acids present diversification in the CDR3 region, and the number of amino acids are variant.

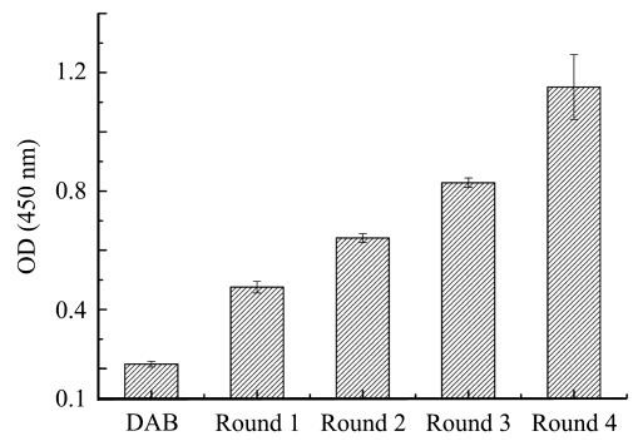

Note: The values of OD were expressed as the mean \pm standard deviations (SD) after being subtracted the control value of three measurements.

Figure 1 Polyclonal ELISA was performed using the original DAB library, or the library which was amplified after each round of panning

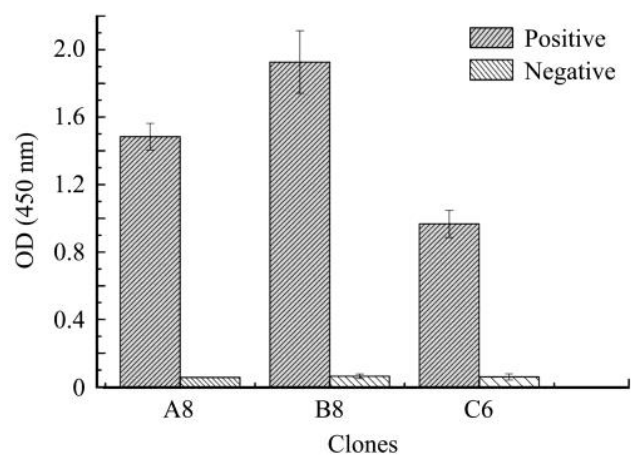

Note: The values of OD were expressed as the mean \pm standard deviations (SD) of three measurements.

Figure 2 Monoclonal ELISA was performed using the clones which were obtained after four round panning

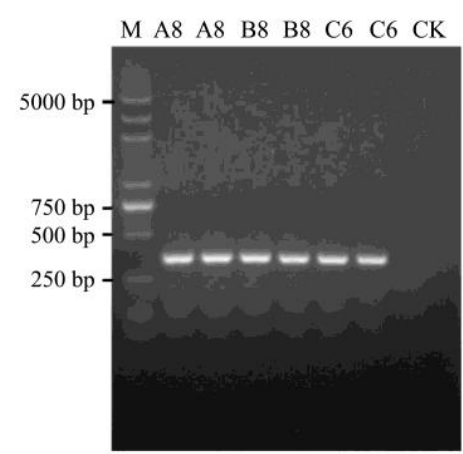

Note: The positive clones with full length gene of domain antibody had stripes at about 360 bp. Lane M: 5000 DNA marker, A8, B8, C6 and CK.

Figure 3 Electropherogram of PCR amplification

\begin{tabular}{|c|c|}
\hline A8 & MKKLLFAI PLVVPFYAAQPAMAQVQLLESGGGLVQPGGSL \\
\hline B8 & MKKLLFAIPLVVPFYAAQPAMAQVQLLESGGGLVQPGGSL \\
\hline C6 & MKKLLFAIPLVVPFYAAQPAMAQVQLLESGGGLVQPGGSL \\
\hline CONSENSUS & MKKLLFAIPLVVPFYAAQPAMAQVQLLESGGGLVQPGGSL \\
\hline & $\mathrm{CDR}-\mathrm{H}_{2}$ \\
\hline A8 & RLSCAASGFKINNYDMGWVRQAPGKGLEWVSGIRGPDGST \\
\hline B8 & RLSCAASGVSFSNNNMGWVRQAPGKGLEWVSSINMTDGST \\
\hline C6 & RLSCAASGVIASHYNMAWVRQAPGKGLEWVSSI I I PDGST \\
\hline CONSENSUS & M WVRQAPGKGLEWVS I \\
\hline A8 & YYADSVKGRFTISRDNSKNTLYLQMNSLRAEDTAVYYCAA \\
\hline B8 & YYADSVKGRFT ISRDNSKNTLYLQMNSLRAEDTAVYYCAG \\
\hline C6 & YYADSVKGRFTISRDNSKNTLYLQMNSLRAEDTAVYYCAT \\
\hline CONSENSUS & $\begin{array}{l}\text { YYADSVKGRFTISRDNSKNTLYLQMNSLRAEDTAVYYCA } \\
\text { CDR-H3 }\end{array}$ \\
\hline A8 & SDCARNIVTFITKPIGFWGQGTLVTVSSAAAEQKLISEED \\
\hline B8 & . RRRRPIQTHMR . . . . YWGQGTLVTVSSAAAEQKLISEED \\
\hline C6 & DMWHEGHAALKS . . . . . WGQGTLVTVSSAAAEQKLISEED \\
\hline CONSENSUS & WGQGTLVTVSSAAAEQKLISEED \\
\hline A8 & LNSAAHYTDIEMNRLGKGAA \\
\hline B8 & LNSAAHYTDIEMNRLGKGAA \\
\hline C6 & LNSAAHYTDIEMNRLGKGAA \\
\hline CON & LNSAAHYTDIEMNRLGKGAA \\
\hline
\end{tabular}

Note: The sequences were translated from the nucleotide sequences (http://web.expasy.org/translate/). Positions of the respective complementarity determining regions of the heavy chain (CDR-H1, CDR-H2, CDR-H3) were indicated in boxes (analyzed by http://www.bioinf.org.uk/abs/).

Figure 4 Amino acid sequences of the positive clones

\subsection{Domain antibody-based competitive ELISA for} pyrethroids

The optimal concentrations of anti-PBA MAb and the titers of A8, B8, and C6 phage particles were performed by the checkerboard titration analysis and the results were presented in Figure 5. The best property was realized with $1.0 \mu \mathrm{g} / \mathrm{mL}$ of anti-PBA MAb and $5 \times 10^{8}$ of phage for A8; $0.5 \mu \mathrm{g} / \mathrm{mL}$ of anti-PBA $\mathrm{MAb}$ and $5 \times 10^{8}$ of phage for B8; $1.0 \mu \mathrm{g} / \mathrm{mL}$ of anti-PBA MAb and $2.5 \times 10^{9}$ of phage for $\mathrm{C} 6$. Under the optimal conditions, the domain antibodies (A8, B8 and C6) were assessed for their properties by using a competitive ELISA and the results were shown in Figure 6. The competitive ELISA established with A8 showed the best property. And the $\mathrm{IC}_{50} \mathrm{~s}$ of competitive ELISA established with A8 were $0.714 \mu \mathrm{g} / \mathrm{mL}$ towards PBA, $1.775 \mu \mathrm{g} / \mathrm{mL}$ towards cypermethrin, $1.624 \mu \mathrm{g} / \mathrm{mL}$ towards $\beta$-cypermethrin, $3.675 \mu \mathrm{g} / \mathrm{mL}$ towards fenvalerate, $4.895 \mu \mathrm{g} / \mathrm{mL}$ towards flucythrinate, respectively. But pyrethroids without phenoxybenzene group, such as resmethrin, transfluthrin, S-bioallethrin showed no significant competitive capacities. The detection limit and the linear range of the ELISA developed with A8 were shown in Table 1. It showed that the domain antibodies had different competitive capacities with the pyrethroids. The possible explanations were (1) the distinct steric parameters and particle charges of atoms or groups in the pyrethroids ${ }^{[25,26]}$, (2) antibodies acted as a receptor or a detector for the analyte in the immunoassay $^{[27]}$, (3) binding affinity, therefore, the assay sensitivity could increase from hydrogen bonding, hydrophobic 
bonding, electrostatic, and van der Waals forces ${ }^{[28]}$.

Using the phage-displayed domain antibody has demonstrated greater advantages compared with soluble expressed domain antibody. Firstly, multiple binding-sites can improve the sensitivity of the developed immunoassay. Secondly, phage

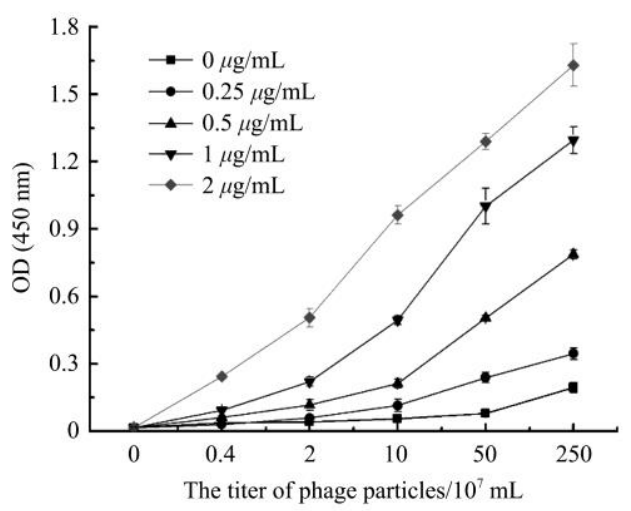

a. $\mathrm{A} 8$

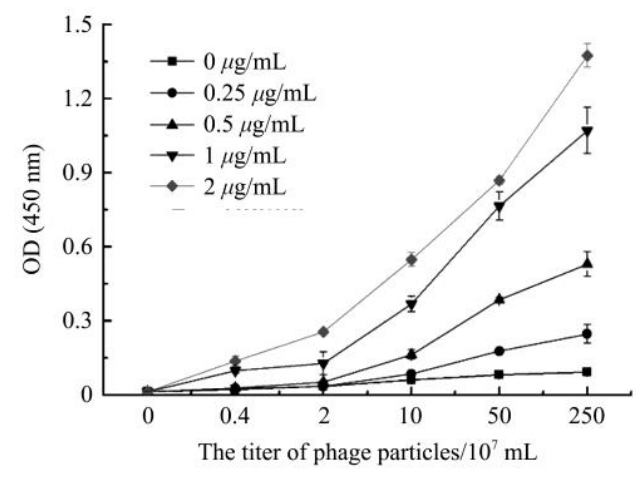

c. C6

Note: The values of OD were expressed as the mean \pm standard deviations (SD) of three measurements.

Figure 5 Results of checkerboard analysis

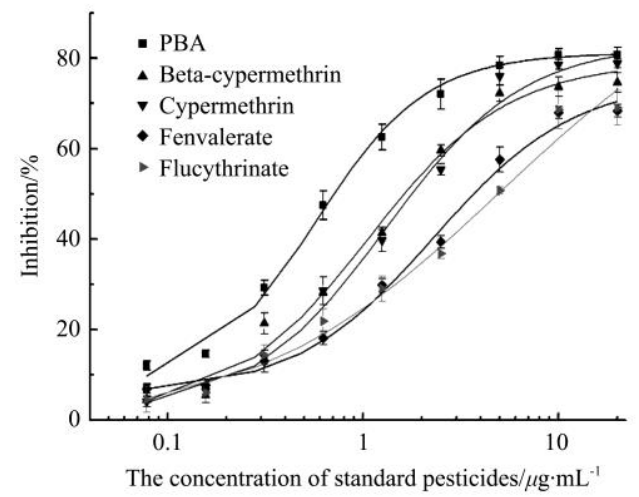

a. A8

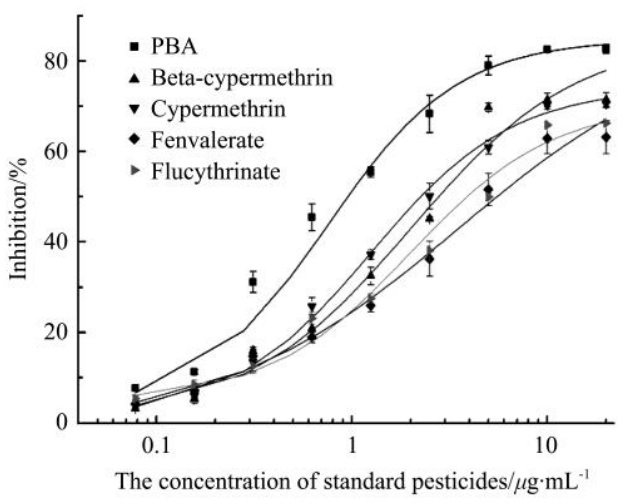

b. B8

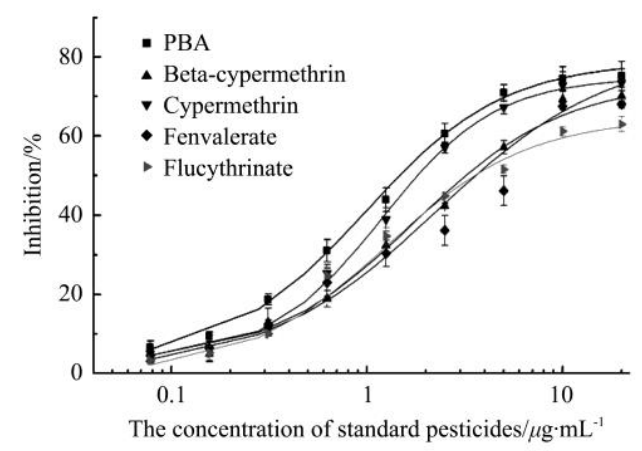

c. C6

Note: The values of OD were expressed as the mean \pm standard deviations (SD) of three measurements.

Figure 6 Inhibition curves of phage-based ELISA 
Table 1 Results of $\mathrm{IC}_{50}$, detection limit and the linear range of PBA and pyrethroids (A8)

\begin{tabular}{lccc}
\hline \multicolumn{1}{c}{ Pesticides } & $\begin{array}{c}\mathrm{IC}_{50} \\
/ \mu \mathrm{g} \cdot \mathrm{mL}^{-1}\end{array}$ & $\begin{array}{c}\text { Detection limit } \\
/ \mu \mathrm{g} \cdot \mathrm{mL}^{-1}\end{array}$ & $\begin{array}{c}\text { Linear range } \\
/ \mu \mathrm{g} \cdot \mathrm{mL}^{-1}\end{array}$ \\
\hline PBA & 0.714 & 0.0566 & $0.256-1.388$ \\
Cypermethrin & 1.775 & 0.229 & $0.422-4.011$ \\
$\beta$-cypermethrin & 1.624 & 0.197 & $0.341-3.315$ \\
Fenvalerate & 3.675 & 0.241 & $0.732-7.247$ \\
Flucythrinate & 4.895 & 0.220 & $0.658-37.689$ \\
Fenpropathrin & $>20$ & $-{ }^{\mathrm{a}}$ & - \\
Deltamethrin & $>20$ & - & - \\
Permethrin & $>20$ & - & - \\
\hline
\end{tabular}

Note: ${ }^{\text {a }}$ The value was not found.

\subsection{Matrix effect and samples analysis}

The Chinese cabbage matrices were selected for the analysis of matrix effects. The results are shown in Table 2, suggesting that there is no remarkable matrix effect in Chinese cabbage matrices.

To evaluate the effectiveness of the assay, the developed ELISA was performed to detect the recovery. The samples spiked with $2 \mu \mathrm{g} / \mathrm{mL}$ and $3 \mu \mathrm{g} / \mathrm{mL}$ of pyrethroids showed the recoveries ranging from $87.4 \%$ to $90.2 \%$ (Table 2). The result proved that the domain antibody-based competitive ELISA could be used to monitor pyrethroids in Chinese cabbage.

Table 2 Matrix effect of sample on the phage ELISA and recovery results

\begin{tabular}{ccccc}
\hline & \multirow{2}{*}{$\begin{array}{c}\text { Spiked } \\
\text { levels }\end{array}$} & \multicolumn{3}{c}{ Recovery $^{\mathrm{a}} / \%$} \\
\cline { 3 - 5 }$/ \mu \mathrm{g} \cdot \mathrm{mL}^{-1}$ & Cypermethrin & Beta-cypermethrin & Fenvalerate \\
\hline \multirow{2}{*}{ Matrix buffer } & 1.0 & $81.1 \pm 1.2$ & $76.8 \pm 1.5$ & $80.8 \pm 1.1$ \\
& 2.0 & $80.6 \pm 2.7$ & $85.6 \pm 1.2$ & $86.7 \pm 1.2$ \\
\hline 2 times dilution of & 1.0 & $84.3 \pm 6.8$ & $82.6 \pm 3.8$ & $84.0 \pm 3.0$ \\
matrix & 2.0 & $89.6 \pm 0.8$ & $87.5 \pm 3.5$ & $89.8 \pm 1.8$ \\
\hline 4 times dilution of & 1.0 & $84.8 \pm 1.3$ & $88.6 \pm 2.4$ & $84.1 \pm 2.6$ \\
matrix & 2.0 & $92.6 \pm 2.9$ & $89.4 \pm 2.5$ & $88.6 \pm 1.6$ \\
\hline Spiked pyrethroids & 2.0 & $88.1 \pm 1.4$ & $88.1 \pm 1.2$ & $87.4 \pm 1.3$ \\
samples & 3.0 & $89.0 \pm 1.3$ & $90.2 \pm 0.5$ & $89.9 \pm 2.1$ \\
\hline
\end{tabular}

Note: ${ }^{\text {a }}$ The values were expressed as the mean \pm standard deviations (SD) of three measurements.

\section{Conclusions}

In this study, the domain antibody $\mathrm{A} 8$ which bound to anti-PBA MAb was selected by the competitive biopanning strategies from a naive phage displayed domain antibody library. The developed immunoassay using A8 showed high sensitivity to pyrethroids. The mimetic antigen can be produced in a relatively short period in large-scale production, and it is also pyrethroid-free, low-cost and environment-friendly. These results indicated that selecting anti-idiotypic from the phage display domain antibody library would be a useful technology to develop immunoassays for the detection of various food chemical contaminants.

\section{Acknowledgements}

This work was supported by Key Science and Technology Project in Henan Province (202102110061, 202102110060, 182102110423) and High Level Talent Research Project of Henan Institute of Science and Technology (2016018, 2016019).

\section{[References]}

[1] Ellis D I, Brewster V L, Dunn W B, Allwood J W, Golovanov A P,
Goodacre R. Fingerprinting food: current technologies for the detection of food adulteration and contamination. Chemical Society Reviews, 2012 41: 5706-5727.

[2] Campàs M, Garibo D, Prieto-Simón B. Novel nanobiotechnological concepts in electrochemical biosensors for the analysis of toxins. Analyst, 2012; 137: 1055-1067.

[3] Cháfer-Pericás C, Maquieira Á, Puchades R. Fast screening methods to detect antibiotic residues in food samples. Trac Trends in Analytical Chemistry, 2010; 29(9): 1038-1049.

[4] Wang Y, Wang Z, Jiang H, Xia X, Shen J, Ding S. Development of a monoclonal antibody-based enzyme-linked immunosorbent assay for the analysis of diclazuril in chicken tissues. Food Analytical Methods, 2013; 6(6): 1685-1692.

[5] Song S, Suryoprabowo S, Liu L, Kuang H, Xu L, Ma W, et al. Development of monoclonal antibody-based colloidal gold immunochromatographic assay for analysis of halofuginone in milk. Food and Agricultural Immunology, 2019; 30(1): 112-122.

[6] Xu Y, Chen B, He Q H, Qiu Y L, Liu X, He Z Y, et al. New approach for development of sensitive and environmentally friendly immunoassay for Mycotoxin Fumonisin B1 based on using Peptide-MBP fusion protein as substitute for coating antigen. Analytical Chemistry, 2014; 86: 8433-8440.

[7] Xu Y, He Z, He Q, Qiu Y, Chen B, Chen J, et al. Use of cloneable peptide-mbp fusion protein as a mimetic coating antigen in the standardized immunoassay for Mycotoxin Ochratoxin A. Journal of Agricultural and Food Chemistry, 2014; 62: 8830-8836.

[8] Shestowsky W S, Holmes C, Hu T, Marr J, Wright J, Chin J, et al. An anti-okadaic acid-anti-idiotypic antibody bearing an internal image of okadaic acid inhibits protein phosphatase PP1 and PP2A catalytic activity. Biochemical and Biophysical Research Communications, 1993; 192: 302-310.

[9] Chanh T C, Rappocciolo G, Hewetson J F. Monoclonal anti-idiotype induces protection against the cytotoxicity of the trichothecene mycotoxin T-2. Journal of Immunology, 1990; 144: 4721-4728.

[10] $\mathrm{Yu} \mathrm{F} \mathrm{Y,} \mathrm{Chu} \mathrm{F} \mathrm{S.} \mathrm{Production} \mathrm{and} \mathrm{characterization} \mathrm{of} \mathrm{a} \mathrm{monoclonal}$ anti-anti-idiotype antibody against fumonisin B1. Journal of Agricultural and Food Chemistry, 1999; 47: 4815-4820.

[11] Guan D, Li P, Cui Y, Zhang Q, Zhang W. A competitive immunoassay with a surrogate calibrator curve for aflatoxin M 1 in milk. Analytica Chimica Acta, 2011; 703: 64-69.

[12] Smith G P. Filamentous fusion phage: Novel expression vectors that display cloned antigens on the virion surface. Science, 1985; 228: 1315-1317.

[13] Wang Y, Wang H, Li P, Zhang Q, Kim H J, Gee S J, et al Phage-displayed peptide that mimics aflatoxins and its application in immunoassay. Journal of Agricultural and Food Chemistry, 2013; 61: 2426-2433.

[14] Wang Y, Li P, Majkova Z, Bever C R, Kim H J, Zhang Q, et al. Isolation of alpaca anti-idiotypic heavy-chain single-domain antibody for the aflatoxin immunoassay. Analytical Chemistry, 2013; 85: 8298-8303.

[15] Liu R, Yu Z, He Q, Xu Y. An immunoassay for ochratoxin A without the mycotoxin. Food Control, 2007; 18: 872-877.

[16] Nejad S M, Veldhuis S L, Richard G, Hall J C. Selection of single chain variable fragment $(\mathrm{scFv})$ antibodies from a hyperimmunized phage display library for the detection of the antibiotic monensin. Journal of Immunological Methods, 2010; 360: 103-118.

[17] González-Techera A, Zon $M$ A, Molina P G, Fernández $H$ González-Sapienza G, Arévalo F J. Development of a highly sensitive noncompetitive electrochemical immunosensor for the detection of atrazine by phage anti-immunocomplex assay. Biosensors and Bioelectronics, 2015; 64: 650-656.

[18] Yin W, Hua X, Liu X, Shi H, Gee S J, Wang M, Hammock B D Development of an enzyme-linked immunosorbent assay for thiacloprid in soil and agro-products with phage-displayed peptide. Analytical Biochemistry, 2015; 481: 27-32.

[19] Yuan Q, Pestka J J, Hespenheide B M, Kuhn L A, Linz J E, Hart L P. Identification of mimotope peptides which bind to the mycotoxin deoxynivalenol-specific monoclonal antibody. Appl. Environmental Microbiology, 1999; 65: 3279-3286.

[20] He Q H, Xu Y, Huang Y H, Liu R R, Huang Z B, Li Y P. Phage-displayed peptides that mimic zearalenone and its application in immunoassay. Food Chemistry, 2011; 126: 1312-1315.

[21] Li Y, Sun Y, Beier R, Lei H, Gee S, Hammock B, et al. Immunochemical 
techniques for multianalyte analysis of chemical residues in food and the environment: A review. Trac-Trends in Analytical Chemistry, 2017; 88: 25-40.

[22] Li C, Luo X, Li Y, Yang H, Liang X, Wen K, et al. A class-selective immunoassay for sulfonamides residue detection in milk using a superior polyclonal antibody with broad specificity and highly uniform affinity. Molecules, 2019; 24(3): 443 .

[23] Wen M T, Liu Y, Yan S, Zhang X, Wang H, Liu X J. Production and identification of broad spectrum monoclonal antibody against a group of pyrethroid insecticides. Chinese Journal of Analytical Chemistry, 2014, 42(9): 1245-1251. (in Chinese)

[24] Lee C M Y, Niccolo I, Frederic S, Daniel C. Selection of human antibody fragments by phage display. Nature Protocols, 2007; 2: 3001-3008.

[25] Zhang Q, Zhang W, Wang X. Immunoassay development for the class-specific assay for types I and II pyrethroid insecticides in water samples. Molecules, 2010; 15: 164-177.

[26] Delaunay-Bertoncini N, Pichon V, Hennion M C. Experimental comparison of three monoclonal antibodies for the class-selective immunoextraction of triazines: Correlation with molecular modeling and principal component analysis studies. Journal of Chromatography A, 2003; 999: 3-15.

[27] Ahn K C, Kim H-J, McCoy M R, Gee S J, Hammock B D Immunoassays and biosensors for monitoring environmental and human exposure to pyrethroid insecticides. Journal of Agricultural and Food Chemistry, 2010; 59: 2792-2802.

[28] Vanderlaan M, Stanker L, Watkins B. Immunoassays for trace chemical analysis: monitoring toxic chemicals in humans, food, and the environment; American Chemical Society; Washington, DC, 1991; Paper No. 2-13. 